\title{
Teaching English Reading through MI Theory in Primary Schools
}

\author{
Jinxiu Jing ${ }^{1}$ \\ ${ }^{1}$ School of Foreign Languages, Leshan Normal University, China \\ Correspondence: Jinxiu Jing, School of Foreign Languages, Leshan Normal University, Leshan, Sichuan, China. \\ Tel: 86-152-2818-0096. E-mail: jinxiu0915@163.com
}

This research is financed by the Research Projects of Leshan Normal University (No.S1230).

Received: October 11, 2012 Accepted: November 20, 2012 Online Published: December 12, 2012

doi:10.5539/elt.v6n1p132 URL: http://dx.doi.org/10.5539/elt.v6n1p132

\begin{abstract}
The theory of Multiple Intelligences (MI theory), put forward by Gardner in 1983, claims that each person possesses different combinations of nine intelligences. In education, it advocates that teachers should address students' personal uniqueness and provide a wide range of intelligence-oriented activities and experiences to facilitate learning, which is consistent with the core idea of the National English Curriculum Standards, namely, English teaching is not only for knowledge, but for the all-round development and the individuality of every student as well. The author conducted an empirical research about application of MI theory in Primary School English class. Two parallel classes were chosen, and one class was taught under the guidance of MI theory, and final evaluations of the two classes were conducted by applying post-tests and interviews. The research data showed that MI-based reading contributed significantly to arousing pupils' interest toward English reading and improving pupils' reading proficiency.
\end{abstract}

Keywords: Multiple Intelligences, MI theory, English reading, primary school

\section{Introduction}

\subsection{The National English Curriculum Standards and MI Theory}

In China, the National English Curriculum Standards carried out in 2001(Revised in 2012) postulates that the main objectives for primary schools are: to develop pupils' interest, self confidence and positive attitude towards learning English; to cultivate the pupils' language sense and enable good pronunciation and intonation; to develop the pupils' preliminary ability to use English in daily exchanges and lay a good basis for further study. The National English Curriculum Standards for primary schools is designed to promote the pupils' overall quality, which allots more attention to pupils' comprehensive development in language skills, knowledge, affects, strategies and cultural awareness in order to lay a good foundation for continuing development (Wang Qiang, 2003). To meet the requirements above in reading class, MI theory could be a good guideline.

MI theory claims that each individual owns at least nine intelligences, namely, mathematical-logical intelligence, musical intelligence, verbal-linguistic intelligence, visual/spatial intelligence, bodily/kinesthetic intelligence, interpersonal intelligence and intrapersonal intelligence, naturalist intelligence, and existential intelligence. MI theory has a great deal in common with the National English Curriculum Standards in terms of educational conceptions. Two basic conceptions of the National English Curriculum Standards clearly stress the focus on the development of intelligences are individuality and learning by doing.

\subsection{Current Situation of English Reading in Primary Schools}

English reading instruction in many primary schools has not received a deserved treatment as required, for teachers feel it hard to adapt to the National English Curriculum Standards and pupils are not interested in English reading as a result. Currently, English reading in primary schools is severely lagged behind, which can be manifested as:

1. Reading instruction for pupils at higher level is still dominated by activities that focus on speaking and listening excessively, lacking ample written inputs.

2. Emphasizing reading result, neglecting training of necessary reading skills. 
3. Many teachers claim that it is not necessary to emphasize primary school pupils' English reading because of their limited vocabulary.

Drawbacks above leave reading instruction in primary schools in a predicament. The malpractices of the classroom teaching, however, have hampered pupils to master the necessary reading skills. Definitely, it is possible to integrate MI theory into teaching reading in primary schools as long as teachers have a comprehensive understanding of the correlation between MI theory and English reading instruction in primary schools. It is assumed that the MI theory will come to be assistance to English educators to enhance pupils' reading proficiency.

\section{Literature Review}

\subsection{An Introduction to MI Theory}

To qualify as"intelligence" the particular capacity under study is considered from multiple perspectives consisting of eight specific criteria drawn from the biological sciences, logical analysis, developmental psychology, experimental psychology, and psychometrics (Christison, 1998). Gardner holds that intelligence is a biopsychological potential to process information that can be activated in a cultural setting to solve problems or create products that are of value in a culture (Gardner, 1999a: 34). The following section summarizes descriptions and contains quotations of the eight intelligences from Gardner's books Frames of Mind: the Theory of Multiple Intelligence (1983).

Verbal/Linguistic Intelligence allows individuals to communicate and make sense of the world through language.

Logical/Mathematical Intelligence enables individuals to use and appreciate abstract relations and understand the underlying principles of some kind of causal system.

Visual-Spatial Intelligence instills people the capacity to think in three-dimensional ways. This intelligence involves sensitivity to color, line, shape, form, space, and the relationships that exist between among elements.

Bodily/Kinesthetic Intelligence includes specific physical skills such as coordination, balance, dexterity, strength, flexibility, and speed, as well as tactile capacities.

Musical Intelligence allows people to create, communicate, and understand meanings made out of sound.

Interpersonal Intelligence enables people to perceive and make distinctions in the moods, intentions, motivations, and feelings of other people.

Intrapersonal Intelligence helps individuals to distinguish among their own feelings, to build accurate mental models of themselves, and to draw on these models to make decisions about their lives.

Naturalist Intelligence allows people to use, classify, and distinguish among features of the environment. They are good at categorizing, organizing a living area, planning a trip, preservation and conservation.

Existential intelligence is about posing and pondering questions about life, death and ultimate realities, and people of this style enjoy thinking, and questioning, and are curios about life, death, and ultimate realities

\subsection{Reviews on the Application of MI Theory}

Campbell (1997) appreciates that MI ideas can influence the creation and implementation of a variety of curriculums. Berman M. (1998) is the first scholar to apply MI Theory to foreign-language teaching practice. In his book A Multiple Intelligences Road to an ELT Classroom (1998), he offers an outline of the MI theory and devotes one chapter to each intelligence to illustrate the variety of exercises/activities/tasks that can be used during English as a foreign language (EFL) lessons to cater for that intelligence type in practice.

Besides, there are many other prominent professors, teacher educators, consultants and experts who have also made considerable contributions to the field of MI such as Armstrong (1994), Lazear, D. (1990, 1994, 1998, 1999, 2003), Christison, M. A. (1996, 1998, 1999). In addition, there are numerous educators who have incorporated MI theory into their work, giving MI theory valuable practical use and suggestions such as Smagorinsky, P (1991, 1995), Haggerty (1995), Jasmine, J (1996), Checkley, K (1997), Costanzo, M\& Paxton, D (1999), Nichoson-Nelson, K.(1998), Silver, H. F. (2000), Altan, M. Z. (2001),Tanner, R (2001), etc. With all these people's contributions, the development of MI in ELT is developing by leaps and bounds. Armstrong T. (2003), In The Multiple Intelligences of Reading and Writing: Making the Words Come Alive, shows how to involve the other seven intelligences to help pupils acquire reading and writing skills. Shearer C. B. (2006) in his PH.D paper analyzed the relevance of reading skills to MI theory.

\subsection{Implications of MI Theory in Education}

"Ml theory is a justification for broadening the curriculum to include a wide variety of courses" (Campbell, B. 
Campbell, L. \& Dickinson, D, 1999: 263). Teachers should reconfigure the traditional curriculum design, and Gardner's MI theory can provide profound implications for this reconfiguration. Teaching design based on MI theory should at least include three different categories of courses:

(1) teaching for multiple intelligences.

(2) teaching with multiple intelligences, which can be regarded as a new pursuit of the teaching method, that is, making intelligences as the means of obtaining knowledge.

(3) teaching about multiple intelligences, which aims to teach pupils to know their own multiple intelligences, including how to evaluate, how to enhance and how to use multiple intelligences actively in study and life.

As Gardner (1993:12) states that it is of the utmost importance that teachers recognize all of the varied intelligences and nurture all of the combinations of intelligences. People are all so different largely because each person has different combinations of intelligences. Recognizing this, people will have at least a better chance of dealing appropriately with the problems they face in the future. In this sense, MI theory is of great usefulness for developing a systematic approach to teach pupils and honor their individual needs within a classroom setting.

\subsection{English Reading and MI Theory}

English reading is an indispensable part in English learning. The Input Hypothesis, which is put forward by Krashen in the late 1970s, states that comprehensible input is the real key to acquiring a language. Krashen and Terrell (1983:131) suggest that "reading may also be a source of comprehensible input in a second language". Therefore, a large amount of comprehensible reading is a good way to acquire a language.

Pupils need to read English materials either for study purpose or simply for pleasure. Through reading, sufficient language input can be ensured. Hence, the goal of language competence will be reached accordingly. Reading materials provide opportunities to study language: vocabulary, grammar, punctuation, and the way native speakers construct sentences and texts. Moreover, reading can introduce interesting topics, stimulate discussion, illicit imaginative responses and be the springboard for well-rounded, fascinating lessons (Harmer, 2000:68). Besides, MI Theory holds that in spite of their differences, the intelligences always take part together in complicated modes. Therefore, in the process of English reading, other intelligences as well as verbal/linguistic intelligences will be exercised to deal with the reading tasks, with each one developed to a certain degree.

\section{Methodology}

\subsection{Research Questions}

The purpose of this study is to present how to apply MI-based teaching in English reading class in primary schools and to testify whether the MI-based classroom teaching can inspire pupils' interest toward English reading; whether the MI-based teaching can improve pupils' English reading proficiency. The present study is designed in such a way that it will meet the requirements postulated in the National Curriculum Standards for primary schools and make up the insufficiencies mentioned above. So this research mainly focuses on the following research questions:

(1) Can the application of MI theory improve primary school pupils' interest toward English reading?

(2) Can the application of MI theory promote pupils' English reading proficiency?

\subsection{Subjects}

This experiment was carried out in Zhongshanlu Primary School, Beibei, Chongqing; and it was conducted within a semester. Two classes in Grade 5 (Class 2 and Class 5) were chosen, and all the subjects had learned English for 4 years since they entered the primary school. The subjects were 59 pupils in all in the experiment, with 29 pupils from Class 2 (the experimental class) and 30 from Class 5 (the control class); The two classes were taught by the same teacher, using the same textbook Starting Line (Book 5A) which was published by People's Education Press (PEP), covering topics like food, animals and plants, personal information, family, school, friends, entertainment and sports, holidays, etc. In the textbook, there are 6 lessons in each unit, among which the third lesson and the fifth are the reading part. The pupils had an English class of 40 minutes in the morning every day. The experimental class was taught under the guidance of MI theory while the control one was taught with the traditional method.

\subsection{Instruments}

\subsubsection{Interview}

Two interviews with the teacher were conducted; one was at the beginning of the experiment, and the other was in the end. As to interest toward English, pupils at this age are still young; they hardly have a clear picture of it 
themselves. It is better to get information concerned from the teacher, for only the teacher is the most qualified and dependable observer in the class. Therefore, the teacher was interviewed twice to identify the reading models used in the two classes and how MI-based reading activities influence pupils' interest toward English reading in the experimental class.

\subsubsection{Test}

In order to testify whether there were any significant difference between the experimental class and the control class, whether MI theory-based teaching could enhance pupils' reading proficiency, pre-test and post-test were conducted to all the subjects involved in the study. The test papers are adapted from official achievement tests of two semesters, so the validity and reliability are guaranteed.

\subsection{Results and Discussion}

\subsubsection{Pre-interview with the Teacher}

Interviewer: The author

Interviewee: Miss Zhang, the present English teacher of the experimental class and the control class. She has taught the two classes for 4 years.

Question 1: Are pupils in these two classes active or passive in English reading class?

Miss Zhang: Most of the pupils in these two classes are active in reading class, especially those who are good at English, while there are also pupils not interested in English reading. Last term, I asked them to subscribe English newspaper. However, it didn't last long because of interest and money. But I have to admit it is a good way to enhance their reading proficiency, for most of them have made great progress in reading at the beginning. I do not know why, just because some like English and some do not.

Question 2. How do you organize activities in English reading class?

Miss Zhang: Generally, I will ask them to look at the pictures first and predicate what is going to happen. Because they are already in Grade 5, I do not favor this way too often, for I think it is not so necessary to do it every time, instead, we get to reading directly.When reading texts, I will ask them some questions or play tape for them, leading them to predicate. I do not like to set goals too high, and the result is not so important. In the checking stage, we have role-play at times, and they like it very much. I always invite pupils who are good at English to take the difficult role, and the rest will take the minor role. I design it in the hope that those with better understanding of English can lead the rest to finish tasks smoothly. Activities used in my class mainly are singing English songs, drawing, flashcards, finish the exercise book and looking up new words in the dictionary.

Question 3. Have you ever heard of MI theory? Have you put it into your teaching practice?

Miss Zhang: Yes, I have heard of it before, but just know little about it. I also want to add something new into my teaching to develop pupils' reading abilities. Sometimes, I will ask them to memorize the passages on the spot, and they really do it, they are so clever. Miss Zhang seems to be very responsible for her pupils. It is obvious that pupils differ a lot in terms of reading proficiency. For those who like English, they are very active in reading class, therefore they will learn more from it; while for those who are not good at English, they are comparatively passive in English class. Children will be active in doing things that they are interested in. If one exerts great efforts in taking up one task, he will learn more from taking part in activities; however, if they think they are not talented, trying means failure, they would not progress in it, for they are not confident. Our goal is to make each student get interested in English and confident in themselves through MI-based activities that catering for individual interest to the utmost.

Miss Zhang is adept in teaching reading, for she is already familiar with the three stages, namely, pre-reading, while-reading and post reading. And she is very clear about goals for each stage, for example, at the pre-reading stage, she develops pupils' predicating ability by asking them to look at the pictures; at the while-reading stage, she asks them to look up new words, training them to use resources to get the meanings; and she says she allots time mainly to the process of reading instead of the result.

From above, even through Miss Zhang has no idea about what is MI theory about, she has already employed some of the techniques, such as songs, pictures, role-play. To some extent, Miss Zhang has unconsciously tried to make use of musical intelligence, visual/spatial intelligence, and bodily/kinesthetic intelligence in her teaching. In our experiment, the author needs to help Miss Zhang develop more intelligence-based activities so to enhance pupils' interest toward English reading and improve their reading proficiency.

\subsubsection{Post-interview with the Teacher}

The interview took place in the second semester following the experiment in attempt to find out whether there 
were any changes in terms of interest toward English reading between the experimental class (Class 2) and the control class (Class 5). The following is details of the post-interview (translated and improved):

Interviewer: The author

Interviewee: Miss Zhang, the present English teacher of the experimental class and the control class.

Post-interviewing questions for the teacher:

Question 1. Is there any difference between the two classes in terms of interest toward English reading in those four months?

Miss Zhang: The two classes were almost at the same level at the beginning of this term. Strangely, Class 2 is more active than Class 5 now. For Class 5, there is no change in interest toward reading, just like before. In this semester, Class 2 has become more active in English reading class, and they start to like reading English newspapers on their own accord. Because the activities in reading class for the Class 2 are more interesting, pupils get active in taking the reading activities. In the past, they were very shy, and I hardly saw they finish the reading tasks enthusiastically. However, now many pupils in Class 2 are more active in participating in activities, and I can feel they become more confident in themselves, everyone can always choose the suitable tasks for himself/herself, and they are happy to be in English reading class. And I find they are much better than Class 5 no matter in understanding texts or self-study, they can even design interesting activities for each other to check appreciation of the texts.

Question 2. What do you think of the application of MI theory in English reading class?

Miss Zhang: During these 4 months, I get to know MI theory more clearly with your help. I believe that in my future teaching, I can be more resourceful in designing various reading activities in my class bearing in mind pupils' individuality. From the MI inventory I have surprisingly noticed that those pupils with strong linguistic intelligence are happy with English learning, enjoy word games and reading, and have a large vocabulary; while those whose language intelligence comparatively underdeveloped, have some difficulty in learning English. In these four months, I have learned how to encourage pupils according to their MI profiles. As a teacher of these two classes, I can sharply feel Class 2 performs much better than Class 5 not only in reading, but also the whole English proficiency.

The post-interview with Miss Zhang reveals that the subjects in the experimental class are more confident and positive and they do better in English reading than those in the control class, once again attesting the hypothesis of this study and the efficacy of the experiment. Because they have got to know MI theory, pupils in Class 2 begin to recognize their own strengths and weaknesses. By giving them the freedom to choose activities they like, they gradually develop a sense of responsibility for their own study. They are able to set goals that they feel they can achieve in English reading class. They think over the problems they meet and try to figure out the solutions. They become more and more active in the learning process. As a whole, more subjects in the experimental class take positive attitudes toward English reading than those in the control class, which is coincident with the author's expectation.

\subsubsection{Pre-test and Post-test}

Pre-test and post-test were conducted at the beginning and the end of the experiment in order to observe if there were any significant differences between the experimental class and the control class. The pre-test and post-test paper were adapted from official achievement tests of the second semester in Grade 4 and the first semester in Grade 5. Pupils in both classes took the tests and the full score of the reading comprehension was 20 points. The scores were gathered and computerized with the Statistical Package for Social Scientist (SPSS13.0).In the boxes blow, the control class is abbreviated as $\mathrm{CC}$, and the experimental class EC; $\mathrm{N}$ stands for the number of pupils.

Table 1. Descriptive statistics for pre-test

\begin{tabular}{ll|l|l|l|l}
\hline & Class & $\mathrm{N}$ & Mean & Std. Deviation & $\begin{array}{l}\text { Std. } \\
\text { Mean }\end{array}$ \\
\hline Pre-test & CC & 30 & 13.5333 & 3.59821 & .65694 \\
\hline & EC & 29 & 13.4828 & 3.52157 & .65394 \\
\hline
\end{tabular}

The descriptive statistics of the reading test for the experimental class and the control class is reported in Table 1 above which reveals that before the experiment the means of the control class and the experimental class are respectively 13.5333 and 13.4828 and that $\mathrm{SD}$ for the control class is 3.59821 and for the experimental class is 3.52157. This makes it reliable that there is little or no statistical difference between the subjects in the 
experimental class and in the control class in the reading test, which suggests that these two classes are at the same starting level in terms of reading proficiency before the experiment.

Table 2. Descriptive statistics for post-test

\begin{tabular}{ll|l|l|l|l}
\hline & Class & $\mathrm{N}$ & Mean & Std. Deviation & $\begin{array}{l}\text { Std. } \\
\text { Mean }\end{array}$ \\
\hline Post-test & CC & 30 & 14.0333 & 3.66233 & .66865 \\
\hline EC & 29 & 16.8621 & 2.41608 & .44865 \\
\hline
\end{tabular}

In the post-test, there is a remarkable change between the control class and the experimental class. For the control class, mean is 14.0333; SD is 3.66233, and for the experimental class, mean is 16.8621 ; SD is 2.41608 . So the mean of the experimental class is higher than that of the control class by 2.82874 . It is very clear that the subjects' reading performances in the experimental class have been greatly improved after MI theory was adopted in the reading teaching.

Now it is clear that the experimental class and the control class beginning with nearly the same reading proficiency before the experiment now differ to some extent. In order to further verify that the mean difference between the experimental class and the control class in the post-test is remarkable, the author does Independent Samples Tests for pre-test and post-test (see Table 3 and Table 4) below. In Table 3, $\mathrm{P}=.957>0.05$, indicating that there is no remarkable mean difference between the control class and the experimental class in pre-test. However, from Table 4 it can be seen clearly that $\mathrm{P}=.001<0.05$, so it can be concluded that the mean difference between the experimental class and the control class is very significant in the post-test. The pupils' reading comprehension proficiency in the experimental class is better than that in the control class after MI theory is applied to their English reading, though they are at the same level at the beginning of the experiment.

Table 3. Independent samples test for pre-test

\begin{tabular}{|c|c|c|c|c|c|c|c|c|c|c|}
\hline & & \multicolumn{2}{|c|}{$\begin{array}{lr}\text { Levene's } & \\
\text { Test for } \\
\text { Equality of } \\
\text { Variances }\end{array}$} & \multicolumn{7}{|c|}{ t-test Equality of Means } \\
\hline & & \multirow[t]{2}{*}{$\mathrm{F}$} & \multirow[t]{2}{*}{ Sig. } & \multirow[t]{2}{*}{$\mathrm{t}$} & \multirow[t]{2}{*}{ df } & \multirow[t]{2}{*}{$\begin{array}{l}\text { sig. } \\
\text { (2-tailed) }\end{array}$} & \multirow[t]{2}{*}{$\begin{array}{l}\text { Mean } \\
\text { Difference }\end{array}$} & \multirow[t]{2}{*}{$\begin{array}{l}\text { Std. Error } \\
\text { Difference }\end{array}$} & \multicolumn{2}{|c|}{$\begin{array}{l}95 \% \text { Confidence } \\
\text { Interval of the } \\
\text { Difference }\end{array}$} \\
\hline & & & & & & & & & Lower & Upper \\
\hline Pre-test & $\begin{array}{l}\text { Equal } \\
\text { variances } \\
\text { assumed } \\
\text { Equal } \\
\text { variances } \\
\text { not } \\
\text { assumed } \\
\end{array}$ & .260 & .612 & .055 & 56.990 & .957 & .05057 & .92728 & -1.80627 & 1.90742 \\
\hline
\end{tabular}

Table 4. Independent samples test for post-test

\begin{tabular}{|c|c|c|c|c|c|c|c|c|c|c|}
\hline & & \multicolumn{2}{|c|}{$\begin{array}{l}\text { Levene's Test } \\
\text { for Equality } \\
\text { of Variances }\end{array}$} & \multicolumn{7}{|c|}{ t-test Equality of Means } \\
\hline & & \multirow[t]{2}{*}{$\mathrm{F}$} & \multirow[t]{2}{*}{ Sig. } & \multirow[t]{2}{*}{$\mathrm{t}$} & \multirow[t]{2}{*}{ df } & \multirow[t]{2}{*}{ sig.(2-tailed) } & \multirow[t]{2}{*}{$\begin{array}{l}\text { Mean } \\
\text { Difference }\end{array}$} & \multirow[t]{2}{*}{$\begin{array}{l}\text { Std. Error } \\
\text { Difference }\end{array}$} & \multicolumn{2}{|c|}{$\begin{array}{l}95 \% \text { Confidence } \\
\text { Interval of the } \\
\text { Difference }\end{array}$} \\
\hline & & & & & & & & & Lower & Upper \\
\hline Pre-test & $\begin{array}{l}\text { Equal } \\
\text { variances } \\
\text { assumed } \\
\text { Equal } \\
\text { variances } \\
\text { not } \\
\text { assumed }\end{array}$ & 4.783 & .033 & -.3489 & 50.409 & .001 & -2.82874 & .81070 & -4.45214 & -1.20533 \\
\hline
\end{tabular}

From the above data analysis, it is obvious that applying task-based teaching to the experimental class for a period of 4 months appropriately facilitates the development of their reading proficiency. Other things being 
equal, except the teaching approach, the mean score of the experimental class in the post-test is significantly higher than that in the control class. This means that teaching based on MI theory, when applied appropriately in English reading class in the primary school, does help develop the pupils' reading proficiency.

\subsection{Discussion}

(1) Can the application of MI theory improve primary school pupils' reading interest?

From post-interview with Miss Zhang, it could be revealed clearly that great differences exist in the performances of two classes. In the experimental class, pupils responded positively to the MI-based teaching and demonstrated a higher level of interest when occupied with various reading activities. They held more positive attitude towards English reading after using MI-based activities in reading for nearly one semester. The data analysis of the results has confirmed the hypothesis of the study stated before that employing MI theory in reading class is more beneficial and effective to stimulate interest than not doing so; pupils in the experimental class applying this new system in reading class take more positive attitude toward reading than those in the control class who do not do so.

Activity designing has played an important role on the issue of arousing pupils' interest toward reading. The traditional class tends to neglect pupils' active involvement, and fails to tap their rich wells of diversity in class. When activities do not accommodate pupils' interest and abilities, pupils will lose interest and feel disengaged. The problem is how to make English reading interesting. There are many causes of low interest, such as self-confidence, study lacking of challenge and a sense of difficulty. Another one is that the relative lacking of freedom and self-determination to choose learning activities they like. In the experimental class, the teacher and the author realized that each individual's intelligences combinations were different, and so teaching needed to satisfy various intelligences otherwise pupils would lose interest. Combining pupils' multiple intelligences, cognitive structures, along with their interest and hobbies, the teacher and the author created a suitable situation of classroom instruction and multimode learning activities for pupils to choose. Like this, the pupils were given opportunities to choose their favorite activities; they could choose the learning activities with difficulty and challenge. By doing so, it made dull reading class challenging so to improve pupils' self-confidence and learning interest.

(2) Can the application of MI theory promote pupils' reading proficiency?

The result, $\mathrm{P}=.001<0.05$ in Table 3.4.3-4, indicates that the incorporation of MI theory in experimental class is truly effective for improving pupils' English reading proficiency. Or it can be said that MI theory has been associated with positive outcomes on standard test.

From the post-interview with Miss Zhang, it can also be pointed out that more attention was paid to pupils' linguistic intelligence, neglecting the other seven kinds of intelligences in the control class. So pupils with advantage in other intelligences could not display their own techniques of understanding of reading nor could they develop the verbal/linguistic intelligences through the other intelligences. It is urgent to improve the traditional teaching. The key point of incorporating MI activities into the experimental classroom was that it allowed all pupils freedom to learn through their strengths and to share their expertise. They were encouraged to make use of all of their techniques of learning as long as it was helpful to reading. Being appreciated for the gifts pupils possessed and appreciating others for their gifts were two marvelous outcomes of the incorporation of MI theory in the classroom in these four months. It went without saying that pupils in the experimental class had developed a deeper understanding of English reading, and at the same time related what they had learned to problems' solution in real life. When viewing the classroom under the guidance of MI theory, teachers who incorporate MI theory into their lessons can better identify children's strengths and present instruction to pupils. Another significant aspect of using MI theory here is that it is a tool to help pupils develop a better understanding and appreciation of their own strengths and learning preferences. If pupils sense out his/her disadvantage in reading or intelligences development, he/she will try to make it up under the guidance of teacher and peer pupils around. Teachers may adapt the language input and accompanying activities to suit the needs of the learners in their classroom. Therefore, teachers should develop lessons that give pupils choices corresponding toughly to combinations of the eight intelligences and observe pupils' learning preferences according to the MI profiles.

In sum, the results of this experiment clearly confirm all the hypotheses of the MI-based reading instruction. Through MI theory, pupils acquire more advanced reading skills and develop into active readers.

\section{Conclusion}

It can be found that the MI-based approach effectively meets the varied needs of the pupils amidst the societal 
changes and realities, and equips pupils with techniques for English reading. Rather than functioning as a prescribed method, curriculum, or technique, MI theory provides a way of understanding intelligence, which can be used as a guide for developing activities that address multiple ways of learning (Christison, 1999). Instead of being static, teaching based on MI theory needs to evolve harmoniously along with pupils' unique and changing needs. Therefore, new methods for implementing MI theory into the classroom should be continually sought out and researched by educators. Holding fast to the New English Curriculum Standards for primary schools, the author and the teacher always tried to design various intelligences-catering activities in English reading class, and pupils were indeed interested in reading which had traditionally been deemed as dull and painstaking.

\section{References}

Altan, M. (2001). Review on intelligence reframed: Multiple intelligences for the 21 century. TESOL Quarterly, 35(1), 294-205. http://dx.doi.org/10.2307/3587873

Armstrong T. (2003). The multiple intelligences of reading and writing: Making the words come alive. Retrieved December 3, 2007 from http://www.simulconference.com/ASCD/2003/scs/2233c.shtml

Armstrong, T. (1994). Multiple intelligences: Seven ways to approach curriculum. Educational Leadership, 52, 26-28.

Berman, M. (1998). A multiple intelligence road to an ELT classroom. Wales, UK: Crown House Publishing Limited.

Campbell, B., Campbell, L., \& Dickinson, D. (1999). Teaching and learning through multiple intelligence. New York: Plume/Penguin.

Campbell, L. (1997). How teachers interpret MI theory. Educational Leadership, 55(1), 15-19.

Checkley, Kathy. (1997). The First Seven and the eighth intelligences. Educational Leadership, 55(1), 8-13.

Chinese Ministry of Education. (2001). (Revised in 2011). National English Curriculum Standards. Beijing: Beijing Normal University Press.

Christison, M. A. (1996). Teaching and learning language through multiple intelligences. TESOL Journal, 6(1), 10-14.

Christison, M. A. (1998). Applying multiple intelligences theory in preservice and inservice TEFL education programs. English Teaching Forum, 3, 3-13.

Christison, M. A. (1999). A guidebook for applying multiple intelligences theory in the ESL/EFL classroom. Burlingame, CA: Alta Book Center.

Costanzo, M., \& Paxton, D. (1999). Multiple assessments for multiple intelligences. Focus on Basics, 3(1), 24-27.

Gardner, H. (1983). Frames of mind: The theory of multiple intelligences. New York: Basic Books.

Gardner, H. (1993). Multiple intelligences: The theory in practice. New York: Basic Books.

Gardner, H. (1999a). Intelligence reframed: Multiple intelligences for the 21st century. New York: Basic Books.

Haggerty, B. A. (1995). Nurturing intelligences: A guide to multiple intelligences theory and teaching. Reading: Addison-Wesley Publishing Company.

Harmer, J. (2000). How to Teach English. Beijing: Foreign Language Teaching and Research Press.

Jasmine, J. (1996). Teaching with multiple Intelligences. Westminster, California: Teacher Created Materials.

Krashen, S., \& T. D. Terrell. (1983). The natural approach: Language acquisition in the classroom. Oxford: Pergamon.

Lazear, D. (1990). Teaching for multiple intelligences. Phi Delta Kappan. Educational Foundation Bloomington, Inc.

Lazear, D. (1994). Multiple intelligence approaches to assessment: Solving the assessment conundrum. Tucson, Arizona: Zephyr Press.

Lazear, D. (1998). The rubrics way: Using MI to assess understanding. Tucson, Arizona: Zephyr Press.

Lazear, D. (2003). Eight ways of teaching: The artistry of teaching with multiple intelligences (4th edition). Person Education.

Nicholson-Nelson, K. (1998). Developing students'multiple intelligences. New York: Scholastic. 
Shearer C. B. (2006). Running head: Reading skill and multiple intelligences. PhD diss., Kent State University.

Silver, H. F., Strong, R. W., \& Perini, M. J. (2000). So each may learn: Integrating learning styles and multiple intelligences. Alexandria, Virginia: Association for Supervision and Curriculum Development.

Smagorinsky, P. (1991). Expressions: Multiple intelligences in the English class. Urbana, Illinois: National Council of Teachers of English.

Smagorinsky, P. (1995). Multiple intelligences in the English class: An overview. English Journal, 84(8), 19-26. http://dx.doi.org/10.2307/821183

Starting Line Students' Book (5A). (2004). Beijing: People's Education Press.

Tanner, R. (2001). MI and You. English Teaching Professional 21, 57-58.

Wang Qiang. (2003). A Course in Primary School English Language Teaching. Beijing: Higher Education Press. 